\title{
Neuronal Network Dissection with Neurotropic Virus Tracing
}

\author{
Xiaoping Rao $^{1} \cdot$ Jie Wang ${ }^{1,2}$
}

Received: 12 January 2020/Accepted: 17 January 2020/Published online: 17 February 2020

(C) Shanghai Institutes for Biological Sciences, CAS 2020

The brain is a marvel of biological evolution, a highly complex organ including hundreds of different types of about 100 billion neurons. Understanding the structure and function of the brain is one of the most challenging scientific questions in the 21 st century. Crucially, the structure of neural circuits and the mechanisms of neuronal information processing related to brain function are still poorly understood [1]. A neural circuit is composed of a large number of synaptically connected neurons of different types and characteristics. It is the structural basis for the execution of various functions, such as perception, emotion, memory, and imagination, as well as other activities. Revealing the structure of neural circuits is the basic premise for understanding the mechanism of information processing in the brain [2].

Traditional neural circuit-tracing methods, such as electron microscopy and Golgi staining, along with dyes and protein/peptide tracers, can depict the morphology of neurons in one brain region and their projections to other regions, as well as trans-synaptic labeling [3]. However, there are some limitations to these tracers and methods, such as extensive deposition, indirect signaling, uncertain direction of spreading, and severe post-synaptic signal

\section{Jie Wang}

jie.wang@wipm.ac.cn

1 Center of Brain Science, State Key Laboratory of Magnetic Resonance and Atomic and Molecular Physics, National Center for Magnetic Resonance in Wuhan, Key Laboratory of Magnetic Resonance in Biological Systems, Wuhan Institute of Physics and Mathematics, Innovation Academy for Precision Measurement Science and Technology, Chinese Academy of Sciences, Wuhan 430071, China

2 The Second Hospital of Shijiazhuang, Shijiazhuang 050051, China attenuation [4]. Neurotropic viruses are a class of viral vectors that can infect neurons and propagate along the neural connections (Fig. 1), such as pseudorabies virus (PRV), herpes simplex virus type 1 (HSV), rabies virus (RV), and vesicular stomatitis virus (VSV) [5]. In addition, some recombinant non-trans-synaptic viral vectors can efficiently label the fine morphology of neurons in vivo, such as Semliki forest virus (SFV) [6], or act as a helper virus to express exogenous genes, such as recombinant adeno-associated virus (AAV) and lentivirus (LV). They can also be used to dissect upstream projections, such as canine adenovirus 2 (CAV2) (Table 1) [5].

Compared with the traditional tracers, the neurotropic viruses have the following characteristics: (I) transmission across synapses, (II) control of the anterograde or retrograde direction of trans-synaptic transmission, (III) replication after crossing synapses without any signal attenuation, and (IV) compatibility with various genetic markers [7]. These characteristics provide unique advantages in the study of structural and functional neural circuits. Nevertheless, there are some limitations or problems for the existing viral tracer systems: (I) tracer tools do not work consistently for different animal models, especially there is a lack of efficient viral tracing tools for primates, (II) the toxicity of existing tools limits their application, such as the long-term functional analysis of neural circuits, (III) low efficiency of expression for some viruses complicates the experimental process, (IV) preparation processes need to be upgraded urgently for the efficient production of high-quality viral vectors, (V) sparse labeling virus systems suitable for local neural circuits need improvement, (VI) the mechanisms by which some viral particles infect neurons are not clear, so the direction of spread across synapses is uncertain, leading to unclear interpretation, and (VII) due to the lack of 


\section{A}

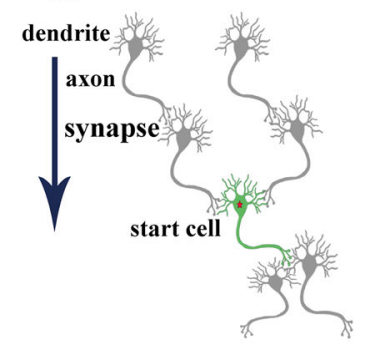

Non-transsynaptic
B

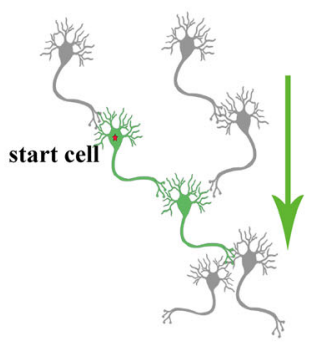

Anterograde monosynaptic
C

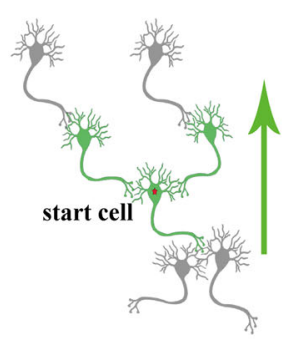

Retrograde monosynaptic
D

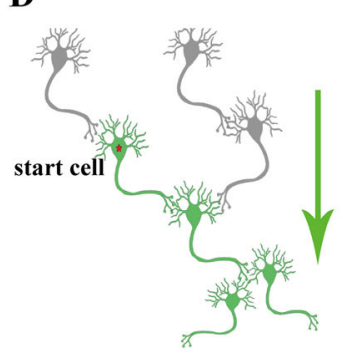

Anterograde multisynaptic
$\mathbf{E}$

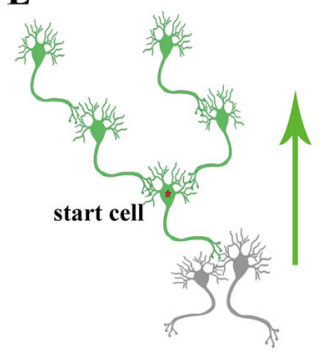

Retrograde multisynaptic

\section{$\longrightarrow$ Direction of information transmission}

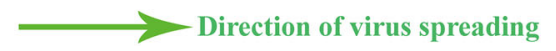

Fig. 1 Direction and numbers of steps of virus spread in neural circuit tracing.

Table 1 Advantages and disadvantages of recombinant viral vectors commonly used in neural circuit tracing [4, 7].

\begin{tabular}{|c|c|c|c|}
\hline Type & Virus tracer & Advantages & Disadvantages \\
\hline \multirow[t]{6}{*}{$\begin{array}{l}\text { Non-trans- } \\
\text { synaptic }\end{array}$} & Adeno-associated virus & $\begin{array}{l}\text { Various serotypes, low immunogenicity, low } \\
\text { cytotoxicity, cell-type specific labeling avail- } \\
\text { able, structural and functional dissection }\end{array}$ & $\begin{array}{l}\text { Vector capacity } \leq 5 \mathrm{~kb} \text {, higher } \\
\text { titer and high purity required in } \\
\text { primates }\end{array}$ \\
\hline & rAAV-retro & $\begin{array}{l}\text { Retrograde tracer, efficient axon terminal } \\
\text { absorption }\end{array}$ & Lower subcortical infection \\
\hline & Canine adenovirus & $\begin{array}{l}\text { Wide range of hosts, retrograde tracer, efficient } \\
\text { axon terminal absorption }\end{array}$ & Cytotoxicity \\
\hline & Semliki forest virus & Non-specific rapid labeling & High cytotoxicity \\
\hline & $\begin{array}{l}\text { Rabies virus (glycoprotein } \\
\text { G-deleted) }\end{array}$ & $\begin{array}{l}\text { Retrograde tracer, efficient infection of axon } \\
\text { endings }\end{array}$ & High cytotoxicity \\
\hline & Herpes simplex virus amplicon & $\begin{array}{l}\text { Retrograde tracer, efficient axon ending absorp- } \\
\text { tion, capacity of } \leq 150 \mathrm{~kb} \text {, wide cellular } \\
\text { tropism, low probability of insertional } \\
\text { mutagenesis }\end{array}$ & Low efficiency, low cytotoxicity \\
\hline \multicolumn{4}{|l|}{ Trans-synaptic } \\
\hline \multirow[t]{2}{*}{$\begin{array}{l}\text { Anterograde, } \\
\text { monosynaptic }\end{array}$} & Herpes simplex virus (TK-deleted) & $\begin{array}{l}\text { Broad host range, anterograde trans-synaptic } \\
\text { spread, large capacity, more genetic elements } \\
\text { available }\end{array}$ & $\begin{array}{l}\text { Low efficiency, high cytotoxicity, } \\
\text { axonal terminal uptake }\end{array}$ \\
\hline & Adeno-associated virus, serotype 1 & $\begin{array}{l}\text { Clear direction of spread, low immunogenicity, } \\
\text { low cytotoxicity, downstream cell-type specific } \\
\text { labeling and structural and functional dissection } \\
\text { available }\end{array}$ & $\begin{array}{l}\text { Unclear trans-synaptic mecha- } \\
\text { nism, high titer required, low } \\
\text { trans-synaptic efficiency, small } \\
\text { capacity }\end{array}$ \\
\hline \multirow[t]{2}{*}{$\begin{array}{l}\text { Retrograde, } \\
\text { monosynaptic }\end{array}$} & Rabies virus, RV $\Delta \mathrm{G}$-EnvA & Clear direction of spread, high efficiency & $\begin{array}{l}\text { High cytotoxicity, potential } \\
\text { leakage }\end{array}$ \\
\hline & Pseudorabies virus (TK-deleted) & $\begin{array}{l}\text { Clear direction of spread, more genetic elements } \\
\text { available }\end{array}$ & $\begin{array}{l}\text { Low trans-synaptic efficiency, } \\
\text { cytotoxicity }\end{array}$ \\
\hline \multirow[t]{2}{*}{$\begin{array}{l}\text { Anterograde, } \\
\text { multisynaptic }\end{array}$} & $\begin{array}{l}\text { Herpes simplex virus 1, HSV1, } \\
\text { H129 }\end{array}$ & $\begin{array}{l}\text { Fast and bright labeling, large capacity, broad } \\
\text { host range }\end{array}$ & $\begin{array}{l}\text { High cytotoxicity, axon terminal } \\
\text { absorption }\end{array}$ \\
\hline & Vesicular stomatitis virus & Fast and bright labeling & High cytotoxicity \\
\hline \multirow[t]{2}{*}{$\begin{array}{l}\text { Retrograde, } \\
\text { multisynaptic }\end{array}$} & Pseudorabies virus, PRV Bartha & $\begin{array}{l}\text { Clear direction of spread, large capacity, more } \\
\text { genetic elements available }\end{array}$ & $\begin{array}{l}\text { High cytotoxicity, low expression } \\
\text { efficiency, does not infect } \\
\text { primates }\end{array}$ \\
\hline & Rabies virus, RV WT & Clear direction of spread & $\begin{array}{l}\text { High cytotoxicity, high } \\
\text { pathogenicity }\end{array}$ \\
\hline
\end{tabular}


comprehensive understanding of the pathogenicity of various viral tracers in different types of neurons in the same animal, the scope of their applicability is vague, leading to inconsistent results (Table 1). Therefore, further development and improvement of viral tracing tools, as well as the establishment of appropriate instructions for use, have become urgent.

In the present issue of Neuroscience Bulletin, Zhu and collaborators [8] compared the efficiency of retrograde gene transduction and neurotropism in three widely-used retrograde virus tracers. They found that the SAD strain of rabies virus $[\operatorname{SAD}-\mathrm{RV}(\Delta \mathrm{G})-\mathrm{N} 2 \mathrm{C}(\mathrm{G})]$, packaged with the $\mathrm{N} 2 \mathrm{C}$ glycoprotein from the CVS strain [9], has a retrograde efficiency comparable to rAAV2-retro, but has a broader tropism in different neural types and regions, especially in subcortical regions. However, rAAV2-retro is more suitable for cortical neural circuit tracing [8]. On the other hand, HSV1 strain H129, widely used as an anterograde tracer, also efficiently infects upstream innervating neurons through axon terminal uptake and displays a clear retrograde labeling phenotype, indicating that there are two types of starter cell: locally infected neurons in the injection site and retrogradely infected neurons [10].

The comparison of the infection mechanism, efficiency, and neurotropism of different viral vectors provides valuable information for the selection of appropriate viral tools for individual research designs [3]. In neural circuit tracing, the qualitative and quantitative analyses of labeled images are also necessary for further analysis. Based on the results [8, 10], different neurotropic viruses have different labeling characteristics in the infected cerebral regions. Results from a single tool might be incomplete and inadequate, thus needing verification with multiple techniques. Thus, there is often no ideal viral tool available for tracing various neural circuits. The researcher must be aware of the advantages and disadvantages of the selected tools or methods to avoid inaccuracy or overgeneralization of the results. At the same time, the results obtained using different tools and methods must be comprehensively compared and analyzed to avoid reaching overgeneralized conclusions.

Acknowledgements This work was supported by the Youth Innovation Promotion Association of the Chinese Academy of Sciences (Y6Y0021004). We thank Zengpeng Han and Huadong Wang at Wuhan Institute of Physics and Mathematics for suggestions and comments on the manuscript and creating the picture and table.

\section{References}

1. Poo M, Xu B, Tan T. Brain science and brain-inspired intelligence technology-an overview. Bull Chin Acad Sci 2016, 31: 725-736.

2. Luo L, Callaway EM, Svoboda K. Genetic dissection of neural circuits. Neuron 2008, 57: 634-660.

3. Lanciego JL, Wouterlood FG. A half century of experimental neuroanatomical tracing. J Chem Neuroanat 2011, 42: 157-183.

4. Saleeba C, Dempsey B, Le S, Goodchild A, McMullan S. A student's guide to neural circuit tracing. Front Neurosci 2019, 13: 897.

5. Zheng N, Su P, Liu Y, Wang H, Nie B, Fang X, et al. Detection of neural connections with ex vivo MRI using a ferritin-encoding trans-synaptic virus. Neuroimage 2019, 197: 133-142.

6. Jia F, Zhu X, Lv P, Hu L, Liu Q, Jin S, et al. Rapid and sparse labeling of neurons based on the mutant virus-like particle of semliki forest virus. Neurosci Bull 2019, 35: 378-388.

7. Li J, Liu T, Dong Y, Kondoh K, Lu Z. Trans-synaptic neural circuit-tracing with neurotropic viruses. Neurosci Bull 2019, 35 : 909-920.

8. Zhu X, Lin K, Liu Q, Yue X, Mi H, Huang X, et al. Rabies Virus pseudotyped with CVS-N2C glycoprotein as a powerful tool for retrograde neuronal network tracing. Neurosci Bull 2019, 10.1007/s12264-019-00423-3.

9. Reardon TR, Murray AJ, Turi GF, Wirblich C, Croce KR, Schnell MJ, et al. Rabies virus CVS-N2c $(\Delta G)$ strain enhances retrograde synaptic transfer and neuronal viability. Neuron 2016 , 89: 711-724

10. Su P, Wang H, Xia J, Zhong X, Hu L, Li Y, et al. Evaluation of retrograde labeling profiles of HSV1 H129 anterograde tracer. J Chem Neuroanat 2019, 100: 101662. 